\title{
Pengaruh Harga, Kualitas Produk, Dan Brand Love Terhadap Loyalitas Pelanggan Pada Minimarket Indomaret
}

\author{
Evi Ambarwati ${ }^{1}$, Tin Agustina $\mathrm{K}^{2}$, Yunus Handoko ${ }^{3}$ \\ STIE ASIA Malang ${ }^{1,2,3}$
}

\begin{abstract}
Modern retail business with the concept of minimarket has experienced a very significant development. Behaviors and lifestyles of consumers who prioritize self service also contribute to the development of the concept of a minimarket, especially in this case are Indomart which is not only a minimarket that provides daily necessities, but also as a cafeteria. The price competition, product quality and brand love of minimarket these days, prioritize customer loyalty.The purpose of this study was to determine and analyze: (1) the effect of prices on customer loyalty in Indomaret GKB-Gresik, (2) the effect of product quality on customer loyalty in Indomaret GKB-Gresik, and (3) the influence of brand love on customer loyalty in Indomaret GKB-Gresik. This research is a field of research conducted using a quantitative approach to Indomart customers who make purchases more than once. The research population is Indomaret GKB - Gresik customers with 100 respondents using accidental sampling method. The data obtained were analyzed using research instrument testing and research hypothesis testing using Statistical Package for the Social Sciences (SPSS) analysis. The results showed that (1) price had a significant effect on customer loyalty at Indomaret GKB - Gresik, (2) product quality had a significant effect on customer loyalty at Indomaret GKB - Gresik, and (3) brand love had a significant effect on customer loyalty at Indomaret GKB Gresik.
\end{abstract}

Keywords: Price, Product quality, Brand Love, Customer Loyalty

\section{Pendahuluan}

Perkembangan bisnis ritel di Indonesia dewasa ini, mengalami pertumbuhan yang signifikan. Menurut Asosiasi Perusahaan Ritel Indonesia (APRINDO), pertumbuhan bisnis ritel Indonesia antara 10\%-15\% per tahun. Yang pada mulanya hanya terdiri atas ritel tradisional dan ritel modern, namun seiring berjalannya waktu, ritel tradisional banyak ditinggalkan oleh para konsumen. Sehingga peningkatan bisnis ritel modern di Indonesia meningkat pesat.

Adapun perbedaan bisnis ritel tradisional dengan ritel modern secara definisi berdasarkan Peraturan Presiden RI No. 112/Thn. 2007 tentang Penataan dan Pembinaan Pasar Tradisional Pusat Perbelanjaan dan Toko Modern, bisnis ritel 
tradisional adalah bisnis yang dibangun dan dikelola oleh Pemerintah, Pemerintah daerah, Swasta, Badan Usaha Milik Daerah termasuk kerjasama dengan swasta dengat tempat usaha berupa toko, kios dan tenda yng dimiliki/dikelola oleh pedangan kecil, menengah, swadaya masyarakat atau koperasi dengan usaha skala kecil, modal kecil dengan proses jual beli barang dagangannya melalui tawar menawar. seperti pasar tradisional, toko kelontong dan lain-lain. Sedangkan ritel modern, yaitu bisnis dengan sistem pelayanan yang mandiri, menjual berbagai jenis barang secara eceran yang berbentuk Minimarket, Supermarket, Department Store, Hypermarket ataupun grosir yang berbentuk Perkulakan.

Perbedaan lainnya yang dihadirkan bisnis ritel tradisional maupun bisnis ritel modern, terletak pada konsepnya yang modern, adanya sentuhan teknologi dan mampu memenuhi perkembangan gaya hidup konsumen telah memberikan nilai lebih dibandingkan dengan market tradisional. Selain itu atmosfer belanja yang lebih bersih dan nyaman, semakin menarik konsumen dan dapat menciptakan budaya baru dalam berbelanja. Sehingga kini di kabupaten atau kota bahkan desa di Indonesia, sudah mulai banyak yang melirik bisnis ritel modern, karena memiliki pengaruh positif terhadap jumlah lapangan pekerjaan dan keuntungannya yang menjanjikan.

Munculnya konsep ritel baru seperti hipermarket, supermarket, dan minimarket, yang termasuk ke dalam jenis ritel modern (pasar modern) merupakan peluang pasar baru yang dinilai cukup potensial oleh para pebisnis ritel, namun dilain sisi dapat mengancam keberadaan pasar tradisional yang belum dapat bersaing dengan pasar modern terutama dalam hal manajemen usaha dan permodalan. Dari waktu ke waktu jumlah pasar modern cenderung mengalami pertumbuhan positif sedangkan pasar tradisional cenderung mengalami pertumbuhan negatif. Bisnis retail seperti minimarket, supermarket, hypermart dan sebagainya adalah bagian dari modernisasi dari pasar tradisional yang memungkinkan orang dapat berbelanja dengan fasilitas dan kenyaman serta pelayanan yang baik, selain itu harga dari setiap produk yang cukup terjangkau.

Perubahan perilaku bisnis tersebut adalah bagian dari pengaruh perilaku pasar yang trend di luar negeri yang kemudian masuk ke Indonesia sejak tahun 
1990an, ditandai dengan dibukanya perusahaan retail besar asal negeri sakura Jepang yaitu "SOGO", sejalan dengan itu mengundang banyak reaksi kritikan, disebabkan Supermarket ini banyak diminati orang, yang berimplikasi pada persaingan pasar, utamanya pada usaha menengah seperti toko produk barang sejenisnya yang nyaris gulung tikar, bahkan sebagian kalangan menilai berdampak buruk terhadap perekonomian di Indonesia.

Di Indonesia itu sendiri bisnis ritel merupakan salah satu sektor yang sangat prospektif. Menurut survey Master Card, Indonesia merupakan Negara dengan pertumbuhan penjualan ritel tertinggi setelah China. Indonesia berada di posisi kedua bersama Hong Kong 07 Agustus 2008. Dari catatan Business Watch Indonesia (BWI) perkembangan ritel modern di Indonesia sejak tahun 2000 semakin pesat yakni sebesar 20\% dan pada tahun 2007 naik menjadi $40 \%$. Perkembangan ritel modern yang begitu pesat secara tidak sadar telah membentuk kekuatan besar dalam industry ritel di Indonesia. Jumlah pendapatan terbesar merupakan kontribusi dari hypermarket, kemudian disusul oleh minimarket dan supermarket. Indonesia masih bertahan di 10 besar dalam Global Retail Development Index (GRDI) 2017 yang dirilis oleh lembaga konsultan A.T Kearney.

Pada 2017, pasar ritel Indonesia berada di posisi 8 dari 30 negara berkembang di seluruh dunia. Dalam daftar GRDI 2017, Indonesia memperoleh skor 55,9 dari skor tertinggi 100 dan berada di urutan 8. Posisi ini turun dari tahun sebelumnya yang berada di urutan 5. Menurut Partner and Head Southeast Asia A.T Kearney Soo Ghee Chua, Indonesia sudah lama menjadi incaran peritel asing. Dibukanya Daftar Negatif Investasi (DNI) membuka peluang bagi investor asing untuk masuk ke pasar ritel domestik, baik untuk menguasai pasar swalayan ataupun e-commerce.

Keragaman bisnis ritel akan membawa implikasi sendiri. Adanya persaingan pada jenis ritel yang sama dan pada sesama bisnis ritel dari kelas yang berbeda. Martinus (2011), menulis bahwa persaingan pada kelompok minimarket, terdapat 2 pemain besar yaitu Indomaret dan Alfamart. Pada kelompok supermarket, terdapat 6 pemain utama yakni Hero, Carrefour, Superindo, 
Foodmart, Ramayana, Yogya dan Griya Supermarket. Pada kelompok hypermarket hanya terdapat 5 peretail dan 3 diantaranya menguasai $88,5 \%$ pangsa revenue hypermarket di Indonesia. Tiga pemain utama tersebut adalah Carrefour yang menguasai hampir 50\% pangsa revenue hypermarket di Indonesia, hypermart (Matahari Putra Prima) dengan pangsa 22,1\%, dan Giant (Hero Grup) dengan 18,5\%. Ditengah ketatnya persaingan diindustri ritel seperti yang sudah dijelaskan diatas, harga menjadi perhatian utama dalam memenangkan persaingan pasar.

Dalam teori marketing, harga merupakan salah satu faktor penting yang mempengaruhi pemasaran suatu produk. Sehingga harga yang ditawarkan menjadi bahan pertimbangan khusus sebelum konsumen memutuskan untuk membeli barang ataupun jasa. Dharmmesta dan Irawan (2008:242), menuliskan ada beberapa tujuan dalam penetapan harga yaitu meningkatkan penjualan, mempertahankan dan memperbaiki market share, stabilitas harga, mencapai target pengambilan investasi, mencapai laba maksimal dan sebagainya. Sehingga agar dapat sukses memasarkan suatu produk, setiap perusahaan harus dapat menetapkan harga secara tepat.

Apalagi ditengah fenomena persaingan yang ada dalam era globalisasi seperti saat ini, akan semakin mengarahkan perusahaan untuk selalu mengembangkan kualitas produk untuk merebut market share (pangsa pasar). Salah satu aset untuk mencapai keadaan tersebut adalah brand (merek) (Durianto et al., 2001). Merek lebih dari sekedar nama dan lambang. Merek adalah elemen kunci dalam hubungan perusahaan dengan konsumen. Merek mempresentasikan persepsi dan perasaan konsumen atas sebuah produk dan kinerjanya semua hal tentang arti produk atau jasa kepada konsumen. Dalam analisis akhir, merek ada dalam pikiran konsumen (Kotler dan Amstrong, 2008).

Nilai nyata dari sebuah merek yang kuat adalah kekuatannya untuk menangkap preferensi dan loyalitas merek. Merek mempunyai jumlah kekuatan dan nilai yang sangat beragam di pasar. Kadang-kadang konsumen terikat sangat erat dengan merek tertentu seperti contoh sangat menyukai dengan produk sepeda motor Suzuki Satria F 150 (Kotler dan Amstrong, 2008). Merek adalah sebuah nama, istilah, tanda, lambang, atau desain atau kombinasi semua ini, yang menunjukkan identitas pembuat atau penjual produk atau jasa. Konsumen memandang merek 
sebagai bagian penting dari produk. Penetapan merek menjadi begitu kuat sehingga saat ini tidak ada produk yang tidak memiliki merek (Kotler dan Amstrong, 2008). Memiliki pelanggan yang memiliki kecintaan terhadap merk tertentu akan menimbulkan loyalitas dalam penggunaan maupun pembelian yang rutin.

Selain itu, produk yang berkualitas juga merupakan salah satu daya tarik pelanggan dalam mengambil keputusan pembelian. Menurut Kotler dan Keller (2016), kualitas produk adalah kemampuan suatu barang untuk memberikan hasil atau kinerja yang sesuai bahkan melebihi dari apa yang diinginkan pelanggan. Semakin berkualitas suatu produk yang ditawarkan dan melebihi ekspektasi pelanggan dengan ditunjang oleh harga yang menarik, maka semakin pelanggan akan memutuskan untuk membeli bahkan kedepannya akan lebih mencintai produk tersebut. Kecintaan pelanggan akan suatu produk dari brand tertentu merupakan salah satu tujuan dari perusahaan dalam membuat produk. Karena dengan mendapatkan pelanggan yang memiliki suatu kecintaan terhadap brand yang dibuat oleh perusahaan, akan semakin timbul kesetiaan pelanggan terhadap brand tersebut.

Perkembangan bisnis retail ini juga dipengaruhi oleh perilaku pelanggan yang dewasa ini lebih nyaman dengan self service. Self service adalah contoh dari customer service yang dioptimalkan, yang memberikan pelanggan lebih banyak kontrol di tangan mereka sendiri dibanding sebelumnya. Sehingga pelanggan memiliki kuasa penuh atas barang yang dipilih dengan label harga yang sudah tertera pada barang. Selain itu, suasana minimarket yang bersih dan nyaman turut menyumbang ramainya pelanggan yang datang untuk melihat - lihat produk dan akhirnya memutuskan untuk melakukan transaksi pembelian.

Di wilayah Gresik, khususnya di GKB (Gresik Kota Baru) sendiri, bisnis retail sudah berkembang pesat. Setidaknya ada lebih dari 10 gerai minimarket baik Alfamart, Indomart, Alfamidi, maupun gerai toko yang mengusung konsep yang sama seperti Alfamart, Indomart, dan Alfamidi. Dari sekian banyak gerai minimarket di wilayah GKB, yang paling banyak dibuka adalah gerai minimarket Indomart dibanding Alfamart maupun Alfamidi. Meskipun mengusung konsep minimarket yang sama, yaitu self service dengan suasana yang bersih dan nyaman, 
serta tata letak produk yang rapi, gerai mini market Indomart memiliki varian produk khas Indomart yang berbeda dengan minimarket lainnya.

Meski hanya ada di beberapa gerai Indomart saja, saat ini Indomart memiliki varian produk kopi, susu, teh, dan minuman jus yang langsung bisa dinikmati melalui mesin pembuat minuman, dalam keadaan panas maupun dingin. Dan disediakan juga tempat hang out untuk menikmati minuman layaknya di kafe. Juga ada produk jajanan seperti sosis dan roti dengan merk Say Bread, yang pemanggangannya dilakukan di depan pelanggan, meski ada juga yang sudah matang. Sehingga ini menjadi nilai tambah daya tarik pelanggan untuk datang untuk sekedar berbelanja atau menikmati minuman langsung dari mesin atau menikmati produk roti.

Berdasarkan fenomena dan studi teoritis maupun empiris di atas, maka penelitian ini mengangkat topik : "Pengaruh Harga, Kualitas Produk, dan Brand Love terhadap Loyalitas Pelanggan (Studi di Indomart GKB - Gresik)”.

Berdasarkan latar belakang diatas, maka rumusan masalah yang dirumuskan antara lain:

1. Apakah harga berpengaruh terhadap loyalitas pelanggan di Indomart GKB Gresik?

2. Apakah kualitas produk berpengaruh terhadap loyalitas pelanggan di Indomart GKB Gresik?

3. Apakah brand love berpengaruh terhadap loyalitas pelanggan di Indomart GKB Gresik?

Sehingga hipotesis pada penelitian ini adalah sebagai berikut:

H1: Diduga harga berpengaruh signifikan terhadap loyalitas pelanggan di Indomaret GKB - Gresik

H2: Diduga kualitas produk berpengaruh signifikan terhadap loyalitas pelanggan di Indomaret GKB - Gresik

Diduga brand love berpengaruh signifikan terhadap loyalitas pelanggan di Indomaret GKB - Gresik

2. Metode Penelitian

Penelitian ini merupakan field research yang dilakukan dengan 
menggunakan pendekatan kuantitatif, yaitu penelitian yang banyak dituntut menggunakan angka, mulai dari pengumpulan data, penafsiran terhadap data tersebut, serta penampilan hasilnya (Arikunto (2013).

\section{Metode Pengambilan Sampel}

Dalam penelitian ini, jumlah populasinya tidak diketahui, sehingga penentuan ukuran sampel dari populasi menggunakan teori yang dikembangkan oleh Isac Michael (Siregar Syofian, 2011), dengan menggunakan rumus sebagai berikut :

$$
\begin{gathered}
\mathrm{n}=\left[\frac{z \frac{a}{2}}{E}\right] 2 \\
\mathrm{n}=\left[\frac{1,96}{0,20}\right] 2 \\
\mathrm{n}=96 \text { responden }
\end{gathered}
$$

Keterangan :

$$
\begin{aligned}
\mathrm{n}=\quad & \text { Ukuran sampel } \\
\mathrm{Za} / 2=\quad & \text { Nilai standar } \\
& \text { daftar luar normal } \\
& \text { standar } \\
& \text { bagaimana tingkat } \\
& \text { kepercayaan (a) } \\
& 95 \% \\
= & \text { Tingkat ketetapan } \\
& \text { yang digunakan } \\
\text { dengan } & \text { mengemukakan } \\
& \text { besarnya eror } \\
& \text { maksimum secara } \\
& 20 \%
\end{aligned}
$$

Dari perhitungan di atas dapat diketahui sampel dalam penelitian ini adalah sebanyak 96 responden, tetapi peneliti membulatkan sampel penelitian menjadi 100 responden yang melakukan dijadikan responden pembelian lebih dari sekali dan dirasa cocok untuk dijadikan responden.

\section{Metode Pengumpulan Data}

Penelitian ini menggunakan metode pengumpulan data berupa observasi, wawancara, dan kuesioner (angket). Observasi dilakukan untuk memperoleh informasi umum minimarket Indomaret GKB - Gresik, sehingga dapat diperoleh data yang dapat menunjang penelitian yang dilakukan penulis. Wawancara juga 
dilakukan hanya kepada beberapa orang untuk memberikan informasi tambahan mengenai harga, kualitas produk, brand love serta loyalitas pelanggan. Kuesioner dengan skala pengukuran yang digunakan adalah skala Likert 5 point.

\section{Definisi Operasional Variabel}

Dalam penelitian ini digunakan 4 (empat) variabel, yaitu: variabel harga (X1), variabel kualitas produk (X2), dan variabel band love (X3) sebagai variabel independen, serta variabel loyalitas pelanggan (Y) sebagai variabel dependen. Adapun definisi operasional variabel penelitian ini secara rinci disajikan dalam tabel berikut.

Tabel 1. Definisi Operasional Variabel Penelitian

\begin{tabular}{|c|c|c|c|c|}
\hline Variabel & Definisi & Indikator & Item & Skala \\
\hline \multirow[t]{5}{*}{ Harga (X1) } & \multirow{5}{*}{$\begin{array}{l}\text { Harga adalah sejumlah uang yang } \\
\text { harus dibayar oleh pembeli untuk } \\
\text { mendapatkan produk tertentu di } \\
\text { Indomart }\end{array}$} & $\begin{array}{l}\text { Jangkauan harga dengan } \\
\text { daya beli konsumen }\end{array}$ & $\begin{array}{l}\text { Harga produk di Indomart } \\
\text { GKB - Gresik terjangkau } \\
\text { oleh semua kalangan }\end{array}$ & \multirow[t]{4}{*}{ Likert } \\
\hline & & \multirow{2}{*}{$\begin{array}{l}\text { Daya saing harga dengan } \\
\text { produk sejenis }\end{array}$} & $\begin{array}{l}\text { Harga produk yang ada di } \\
\text { Indomart GKB - Gresik } \\
\text { sesuai dengan promosi yang } \\
\text { ditawarkan }\end{array}$ & \\
\hline & & & $\begin{array}{l}\text { Harga produk yang ada di } \\
\text { Indomaret GKB - Gresik } \\
\text { memiliki daya saing yang } \\
\text { kuat dengan minimarket } \\
\text { lainnya }\end{array}$ & \\
\hline & & $\begin{array}{l}\text { Kesesuaian harga dengan } \\
\text { kualitas }\end{array}$ & $\begin{array}{l}\text { Produk yang ada di } \\
\text { Indomaret GKB - Gresik } \\
\text { memiliki harga yang sesuai } \\
\text { dengan kualitas produk dan } \\
\text { pelayanan yang diberikan }\end{array}$ & \\
\hline & & \multicolumn{3}{|l|}{ Tjiptono (2008) } \\
\hline \multirow[t]{4}{*}{$\begin{array}{l}\text { Kualitas } \\
\text { produk }(X 2)\end{array}$} & \multirow{4}{*}{$\begin{array}{l}\text { Kualitas produk adalah } \\
\text { kemampuan suatu produk yang } \\
\text { diperjualbelikan di Indomart } \\
\text { untuk menunjukkan berbagai } \\
\text { fungsi termasuk ketahanan, } \\
\text { keterandalan, ketepatan, dan } \\
\text { kemudahan dalam penggunaan. }\end{array}$} & $\begin{array}{l}\text { Kualitas produk yang } \\
\text { dijual lebih baik dari } \\
\text { perusahaan lain }\end{array}$ & $\begin{array}{l}\text { Saya merasa kualitas produk } \\
\text { di Indomaret GKB - Gresik } \\
\text { lebih bagus daripada di toko } \\
\text { tradisional }\end{array}$ & \multirow[t]{3}{*}{ Likert } \\
\hline & & $\begin{array}{l}\text { Kualitas barang sesuai } \\
\text { dengan apa yang } \\
\text { diharapkan konsumen }\end{array}$ & $\begin{array}{l}\text { Indomaret GKB - Gresik } \\
\text { memiliki produk yang } \\
\text { beragam sesuai dengan } \\
\text { kebutuhan konsumennya }\end{array}$ & \\
\hline & & $\begin{array}{l}\text { Barang yang dijual lebih } \\
\text { terjamin mutunya } \\
\text { daripada perusahaan } \\
\text { lainnya }\end{array}$ & $\begin{array}{l}\text { Saya merasa produk yang ada } \\
\text { di Indomaret GKB - Gresik } \\
\text { sesuai dengan kebutuhan } \\
\text { saya }\end{array}$ & \\
\hline & & \multicolumn{3}{|l|}{ Fuad (2013) } \\
\hline \multirow[t]{2}{*}{$\begin{array}{l}\text { Brand Love } \\
\text { (X3) }\end{array}$} & \multirow{2}{*}{$\begin{array}{l}\text { Brand love adalah tingkatan } \\
\text { ikatan emosional dan keinginan } \\
\text { yang dimiliki oleh seorang } \\
\text { pelanggan Indomart }\end{array}$} & $\begin{array}{l}\text { Mengenal merek sebagai } \\
\text { merek yang sangat bagus }\end{array}$ & $\begin{array}{l}\text { Indomaret GKB - Gresik } \\
\text { merupakan salah satu } \\
\text { minimarket yang bagus } \\
\end{array}$ & Likert \\
\hline & & $\begin{array}{l}\text { Memiliki keterikatakan } \\
\text { terhadap merek }\end{array}$ & $\begin{array}{l}\text { Pelanggan merasa tidak ada } \\
\text { minimarket lain yang dapat }\end{array}$ & \\
\hline
\end{tabular}




\begin{tabular}{|c|c|c|c|c|}
\hline Variabel & Definisi & Indikator & Item & Skala \\
\hline & & & $\begin{array}{l}\text { memenuhi kepuasan saya } \\
\text { selama berbelanja selain di } \\
\text { Indomaret GKB - Gresik }\end{array}$ & \\
\hline & & $\begin{array}{l}\text { Memiliki penilaian } \\
\text { positif terhadap merek }\end{array}$ & $\begin{array}{l}\text { Pelanggan memiliki } \\
\text { pemikiran yang positif } \\
\text { terhadap minimarket } \\
\text { Indomaret GKB - Gresik } \\
\end{array}$ & \\
\hline & & $\begin{array}{l}\text { Memiliki emosi yang } \\
\text { positif dalam merespon } \\
\text { merek }\end{array}$ & $\begin{array}{l}\text { Pelanggan memiliki } \\
\text { pemikiran yang positif } \\
\text { terhadap minimarket } \\
\text { Indomaret GKB - Gresik }\end{array}$ & \\
\hline & & $\begin{array}{l}\text { Pernyataan kecintaannya } \\
\text { terhadap merek }\end{array}$ & $\begin{array}{l}\text { Pelanggan cinta terhadap } \\
\text { minimarket Indomaret GKB } \\
\text { - Gresik }\end{array}$ & \\
\hline & & \multicolumn{3}{|c|}{ Ismail et al. (2012) dan Albert et al. (2013) } \\
\hline \multirow[t]{4}{*}{$\begin{array}{l}\text { Loyalitas } \\
\text { pelanggan } \\
(\mathrm{Y})\end{array}$} & \multirow{4}{*}{$\begin{array}{l}\text { Loyalitas pelanggan adalah suatu } \\
\text { kesediaan pelanggan untuk } \\
\text { melanjutkan pembelian di } \\
\text { Indomart dalam jangka waktu } \\
\text { yang panjang dan menggunakan } \\
\text { produk dan pelayanan di } \\
\text { Indomart secara berulang }\end{array}$} & Say positive things & $\begin{array}{l}\text { Pelanggan akan menceritakan } \\
\text { hal-hal positif kepada orang } \\
\text { lain mengenai Indomaret } \\
\text { GKB - Gresik }\end{array}$ & \multirow[t]{2}{*}{ Likert } \\
\hline & & Recommend to friend & $\begin{array}{l}\text { Pelanggan dengan senang } \\
\text { hati merekomendasikan } \\
\text { kepada orang lain agar } \\
\text { berbelanja di Indomaret GKB } \\
\text { - Gresik }\end{array}$ & \\
\hline & & Continue purchasing & $\begin{array}{l}\text { Ketika hendak berbelanja, } \\
\text { pelanggan lebih memilih } \\
\text { Indomaret GKB - Gresik } \\
\text { daripada minimarket lainnya }\end{array}$ & \\
\hline & & \multicolumn{3}{|l|}{ Zeithaml et al. (1996) } \\
\hline
\end{tabular}

\section{Metode Analisis Data}

Penelitian ini akan menggunakan analisis deskriptif karakteristik responden, analisis deskriptif jawaban responden, uji instrument penelitian, uji asumsi klasik, dan uji hipotesis. Adapun alat bantu yang digunakan adalah program SPSS Versi 25.

Analisis deskriptif karakteristik responden ditinjau berdasarkan jenis kelamin, usia, pendidikan terakhir, pekerjaan, frekuensi pembelian di Indomaret, dan pengeluaran rata-rata per bulan. Sedangkan pada analisis deskriptif jawaban responden, kriteria nilai rata-rata untuk setiap item kuesioner adalah sebagai berikut:
a. Sangat baik
$=4<$ mean $\leq 5$
b. Baik
$=3<$ mean $\leq 4$
c. Kurang Baik
$=2<$ mean $\leq 3$ 
d. Tidak Baik $=1<$ mean $\leq 2$

Pada uji instrument penelitian, dilakukan uji validitas dan reliabilitas. Uji validitas menggunakan korelasi product moment yang dikemukakan oleh Pearson (Bachtiar, 2011). Dengan jumlah sampel sebanyak 100 responden dan tingkat signifikansi 0,05, maka berdasarkan tabel signifikansi Product Moment didapatkan $\mathrm{r}_{\text {tabel }}$ sebesar 0,05. Untuk uji reliabilitas menggunakan nilai Alpha Cronbach (Arikunto, 2006).

Dalam uji asumsi klasik dilakukan 3 uji, yaitu uji normalitas, uji multikolinearitas, dan uji heteroskedastisitas. Uji normalitas menggunakan uji Kolmogorov-Smirnov pada nilai residualnya. Uji multikolinearitas berdasarkan pada nilai VIF dan toleransinya. Uji heteroskedastisitas berdasarkan pengamatan grafik nilai residualnya. Pada uji hipotesis, dilakukan analisis regresi berganda dan analisis koefisien determinasi. Pada uji ini digunakan uji t untuk mengetahui pengaruh variabel independen terhadap variabel dependen secara parsial. Adapun model penelitian adalah sebagai berikut:

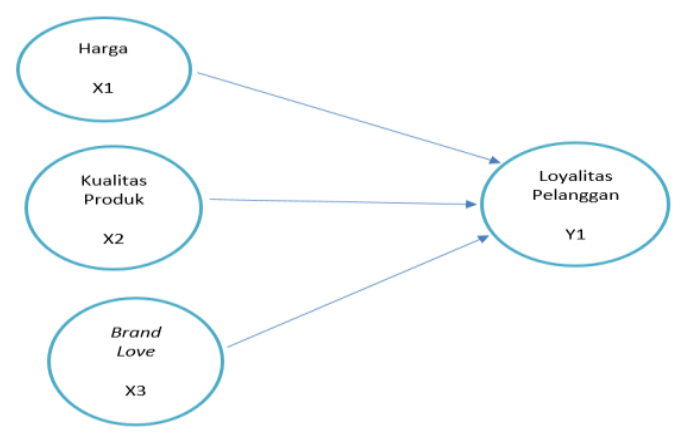

Gambar 1. Model Penelitian

\section{Hasil Dan Pembahasan}

\section{Deskriptif Karakteristik Responden}

Karakteristik responden ditinjau berdasarkan jenis kelamin, usia, dan lama bekerja responden disajikan dalam tabel berikut:

Tabel 2. Data Responden 


\begin{tabular}{|c|c|c|c|}
\hline Profil & Uraian & $\begin{array}{l}\text { Frekuensi } \\
\text { (orang) }\end{array}$ & $\begin{array}{l}\text { Persentase } \\
(\%)\end{array}$ \\
\hline \multirow{3}{*}{ Jenis Kelamin } & Laki-Laki & 31 & $31 \%$ \\
\hline & Perempuan & 69 & $69 \%$ \\
\hline & Total & 100 & $100 \%$ \\
\hline \multirow{5}{*}{ Usia } & $>40$ tahun & 17 & $17 \%$ \\
\hline & $17-20$ tahun & 19 & $19 \%$ \\
\hline & $21-30$ tahun & 34 & $34 \%$ \\
\hline & $31-40$ tahun & 30 & $30 \%$ \\
\hline & Total & 100 & $100 \%$ \\
\hline \multirow{5}{*}{ Pendidikan Terakhir } & Diploma & 31 & $31 \%$ \\
\hline & Lainnya & 20 & $20 \%$ \\
\hline & Sarjana & 22 & $22 \%$ \\
\hline & SMA/Sederajat & 27 & $27 \%$ \\
\hline & Total & 100 & $100 \%$ \\
\hline \multirow{7}{*}{ Pekerjaan } & Ibu Rumah Tangga & 17 & $17 \%$ \\
\hline & Lainnya & 13 & $13 \%$ \\
\hline & Pegawai negeri & 8 & $8 \%$ \\
\hline & Pegawai swasta & 28 & $28 \%$ \\
\hline & Pelajar/Mahasiswa & 23 & $23 \%$ \\
\hline & Wirausaha & 11 & $11 \%$ \\
\hline & Total & 100 & $100 \%$ \\
\hline
\end{tabular}




\begin{tabular}{|c|c|c|c|}
\hline \multirow{4}{*}{$\begin{array}{l}\text { Frekuensi } \\
\text { Pembelian }\end{array}$} & $2-4$ kali & 37 & $37 \%$ \\
\hline & $5-7 \mathrm{kali}$ & 25 & $25 \%$ \\
\hline & $8-10$ kali & 16 & $16 \%$ \\
\hline & $>10$ kali & 22 & $22 \%$ \\
\hline & Total & 100 & $100 \%$ \\
\hline \multirow{6}{*}{$\begin{array}{l}\text { Pengeluaran } \\
\text { Rata-rata/bln }\end{array}$} & $<500.000$ & 10 & $10 \%$ \\
\hline & $>3.000 .000$ & 15 & $15 \%$ \\
\hline & $1.000 .000-2.000 .000$ & 20 & $20 \%$ \\
\hline & $2.000 .000-3.000 .000$ & 30 & $30 \%$ \\
\hline & $500.000-1.000 .000$ & 25 & $25 \%$ \\
\hline & Total & 100 & $100 \%$ \\
\hline
\end{tabular}

Berdasarkan hasil analisis deskriptif kelima karakteristik responden, diketahui bahwa mayorits responden laki - laki lebih sedikit dari responden perempuan, yaitu $31 \%$ responden laki - laki dan $69 \%$ responden perempuan. Berdasarkan usia diketahui mayoritas sampel berada pada rentang usia 21-30 tahun (34\%). Hal ini menunjukan bahwa pada rentang usia $21-30$ tahun adalah usia aktif bekerja dimana kecenderungan untuk melakukan aktivitas belanja lebih tinggi daripada usia-usia sebelum atau sesudah itu. Berdasarkan pendidikan terakhir diketahui mayoritas sample memiliki pendidikan terakhir Diploma sebanyak 31\%, SMA sebanyak $27 \%$ sisanya Sarjana 22\% dan lainnya 20\%. Berdasarkan pekerjaan diketahui bahwa mayoritas sampel merupakan pekerja swasta dengan prosentase $28 \%$, kemudian disusul oleh pekerjaan sebagai pelajar / mahasiswa dengan prosentase 23\%. Berdasarkan frekuensi pembelian diketahui bahwa mayoritas sampel melakukan pembelian di Indomaret GKB - Gresik lebih antara 2 - 4 kali. Hal ini menunjukan bahwa mayoritas sampel lebih menyukai melakukan aktivitas berbelanja di Indomaret. Berdasarkan pengeluaran rata-rata per bulan diketahui bahwa mayoritas sampel melakukan menghabiskan sekitar 2.000.000 - 3.000.000 
untuk pngeluaran rata-rata per bulan yang dihabiskan untuk melakukan transaksi pembelanjaan. Jadi besar kemungkinan pembelanjaan dilakukan sebagian besar di minimarket.

\section{Deskriptif Jawaban Responden}

Berikut disajikan analisis deskriptif jawaban responden dari setiap pernyataan- pernyataan yang disajikan dalam kuisioner.

Tabel 3. Statistik Deskriptif Item Kuesioner

\begin{tabular}{|c|c|c|c|c|c|c|c|}
\hline \multirow{2}{*}{ Item } & \multicolumn{5}{|c|}{ Pemilihan Jawaban (\%) } & \multirow{2}{*}{ Mean } & \multirow{2}{*}{ Ket } \\
\hline & STS & $\mathrm{TS}$ & $\mathrm{CS}$ & $\mathrm{S}$ & SS & & \\
\hline \multicolumn{8}{|c|}{ Harga } \\
\hline X1.1 & $1 \%$ & $1 \%$ & $4 \%$ & $59 \%$ & $35 \%$ & 4,26 & SB \\
\hline $\mathrm{X} 1.2$ & $1 \%$ & $1 \%$ & $11 \%$ & $48 \%$ & $39 \%$ & 4,23 & SB \\
\hline $\mathrm{X} 1.3$ & $1 \%$ & $3 \%$ & $21 \%$ & $50 \%$ & $25 \%$ & 3,95 & $\mathrm{~B}$ \\
\hline $\mathrm{X} 1.4$ & $1 \%$ & $4 \%$ & $21 \%$ & $51 \%$ & $23 \%$ & 3,91 & B \\
\hline \multicolumn{8}{|c|}{ Kualitas Produk } \\
\hline $\mathrm{X} 2.1$ & $0 \%$ & $1 \%$ & $35 \%$ & $53 \%$ & $11 \%$ & 3.73 & B \\
\hline $\mathrm{X} 2.2$ & $0 \%$ & $3 \%$ & $26 \%$ & $58 \%$ & $13 \%$ & 3.81 & B \\
\hline $\mathrm{X} 2.3$ & $1 \%$ & $0 \%$ & $27 \%$ & $56 \%$ & $16 \%$ & 3.86 & B \\
\hline \multicolumn{8}{|c|}{ Brand Love } \\
\hline $\mathrm{X} 3.1$ & $1 \%$ & $0 \%$ & $28 \%$ & $62 \%$ & $9 \%$ & 3,78 & B \\
\hline $\mathrm{X} 3.2$ & $0 \%$ & $2 \%$ & $30 \%$ & $59 \%$ & $9 \%$ & 3,75 & $\mathrm{~B}$ \\
\hline $\mathrm{X} 3.3$ & $1 \%$ & $3 \%$ & $28 \%$ & $46 \%$ & $22 \%$ & 3,85 & $\mathrm{~B}$ \\
\hline $\mathrm{X} 3.4$ & $0 \%$ & $5 \%$ & $25 \%$ & $56 \%$ & $14 \%$ & 3,79 & $\mathrm{~B}$ \\
\hline $\mathrm{X} 3.5$ & $1 \%$ & $10 \%$ & $15 \%$ & $54 \%$ & $20 \%$ & 3,82 & $\mathrm{~B}$ \\
\hline \multicolumn{8}{|c|}{ Loyalitas Pelanggan } \\
\hline Y1.1 & $1 \%$ & $0 \%$ & $29 \%$ & $50 \%$ & $20 \%$ & 3.88 & $\mathrm{~B}$ \\
\hline Y1.2 & $0 \%$ & $1 \%$ & $17 \%$ & $45 \%$ & $37 \%$ & 4.18 & SB \\
\hline Y1.3 & $0 \%$ & $0 \%$ & $17 \%$ & $45 \%$ & $38 \%$ & 4.21 & SB \\
\hline
\end{tabular}

Tabel 4. Statistik Deskriptif Indikator

\begin{tabular}{|c|c|c|c|c|}
\hline Indikator & Item & Nilai & Mean & Ket \\
\hline \multicolumn{5}{|c|}{ Harga } \\
\hline $\begin{array}{c}\text { Jangkauan } \\
\text { harga dengan } \\
\text { daya beli } \\
\text { konsumen } \\
\end{array}$ & X1.1 & 4,26 & \multirow{4}{*}{4,09} & \multirow{4}{*}{$\begin{array}{c}\text { Sangat } \\
\text { baik }\end{array}$} \\
\hline \multirow{2}{*}{$\begin{array}{c}\text { Daya saing } \\
\text { harga dengan } \\
\text { produk sejenis }\end{array}$} & $\mathrm{X} 1.2$ & 4,23 & & \\
\hline & $\mathrm{X} 1.3$ & 3,95 & & \\
\hline $\begin{array}{l}\text { Kesesuaian } \\
\text { harga dengan } \\
\text { kualitas }\end{array}$ & $\mathrm{X} 1.4$ & 3,91 & & \\
\hline \multicolumn{5}{|c|}{ Kualitas Produk } \\
\hline $\begin{array}{c}\text { Kualitas produk } \\
\text { yang dijual } \\
\text { lebih baik dari }\end{array}$ & $\mathrm{X} 2.1$ & 3.73 & 4,3 & $\begin{array}{c}\text { Sangat } \\
\text { baik }\end{array}$ \\
\hline
\end{tabular}




\begin{tabular}{|c|c|c|c|c|}
\hline Indikator & Item & Nilai & Mean & Ket \\
\hline perusahaan lain & & & & \\
\hline $\begin{array}{l}\text { Kualitas barang } \\
\text { sesuai dengan } \\
\text { apa yang } \\
\text { diharapkan } \\
\text { konsumen }\end{array}$ & $\mathrm{X} 2.2$ & 3.81 & & \\
\hline $\begin{array}{c}\text { Barang yang } \\
\text { dijual lebih } \\
\text { terjamin } \\
\text { mutunya } \\
\text { daripada } \\
\text { perusahaan } \\
\text { lainnya }\end{array}$ & $\mathrm{X} 2.3$ & 3.86 & & \\
\hline \multicolumn{5}{|c|}{ Brand Love } \\
\hline $\begin{array}{c}\text { Mengenal } \\
\text { merek sebagai } \\
\text { merek yang } \\
\text { sangat bagus }\end{array}$ & $\mathrm{X} 3.1$ & 3,78 & \multirow{4}{*}{3,79} & \multirow{4}{*}{ Baik } \\
\hline $\begin{array}{c}\text { Memiliki } \\
\text { keterikatakan } \\
\text { terhadap merek }\end{array}$ & X3.2 & 3,75 & & \\
\hline $\begin{array}{c}\text { Memiliki } \\
\text { penilaian } \\
\text { positif terhadap } \\
\text { merek }\end{array}$ & X3.3 & 3,85 & & \\
\hline $\begin{array}{l}\text { Memiliki emosi } \\
\text { yang positif } \\
\text { dalam } \\
\text { merespon } \\
\text { merek }\end{array}$ & X3.4 & 3,79 & & \\
\hline $\begin{array}{c}\text { Pernyataan } \\
\text { kecintaannya } \\
\text { terhadap merek }\end{array}$ & $\mathrm{X} 3.5$ & 3,82 & & \\
\hline \multicolumn{5}{|c|}{ Loyalitas Pelanggan } \\
\hline $\begin{array}{c}\text { Say positive } \\
\text { things }\end{array}$ & Y1.1 & 3.88 & \multirow{3}{*}{4,09} & \multirow{3}{*}{$\begin{array}{c}\text { Sangat } \\
\text { baik }\end{array}$} \\
\hline $\begin{array}{l}\text { Recommend to } \\
\text { friend }\end{array}$ & Y1.2 & 4.18 & & \\
\hline $\begin{array}{c}\text { Continue } \\
\text { purchasing }\end{array}$ & Y1.3 & 4.21 & & \\
\hline
\end{tabular}

Berdasarkan tabel diatas diketahui bahwa sebagian besar responden menjawab setiap item kuesioner dengan jawaban sangat setuju. Sehingga dapat diketahui bahwa harga, kualitas produk, brand love, dan loyalitas pelanggan pada minimarket Indomart GKB - Gresik sudah sangat baik.

\section{Uji Instrument Penelitian}

Pada penelitian ini dilakukan uji instrument penelitian untuk memastikan data yang digunakan valid dan reliabel (dapat diandalkan). 
Tabel 5. Hasil Uji Validitas

\begin{tabular}{|c|c|c|c|c|}
\hline Indikator & $\mathbf{r}_{\text {hitung }}$ & $\mathbf{r}_{\text {tabel }}$ & Sig & Ket \\
\hline \multicolumn{5}{|c|}{ Harga } \\
\hline X1.1 & 0,731 & 0,05 & 0,000 & Valid \\
\hline X1.2 & 0,808 & 0,05 & 0,000 & Valid \\
\hline X1.3 & 0,810 & 0,05 & 0,000 & Valid \\
\hline X1.4 & 0,838 & 0,05 & 0,000 & Valid \\
\hline \multicolumn{5}{|c|}{ Kualitas Produk } \\
\hline X2.1 & 0,837 & 0,05 & 0,00 & Valid \\
\hline X2.2 & 0,847 & 0,05 & 0,00 & Valid \\
\hline X2.3 & 0,799 & 0,05 & 0,00 & Valid \\
\hline \multicolumn{5}{|c|}{ Brand Love } \\
\hline X3.1 & 0,646 & 0,05 & 0,000 & Valid \\
\hline X3.2 & 0,558 & 0,05 & 0,000 & Valid \\
\hline X3.3 & 0,799 & 0,05 & 0,000 & Valid \\
\hline X3.4 & 0,803 & 0,05 & 0,000 & Valid \\
\hline X3.5 & 0,798 & 0,05 & 0,000 & Valid \\
\hline \multicolumn{5}{|c|}{ Loyalitas Pelanggan } \\
\hline Y1.1 & 0,783 & 0,05 & 0,000 & Valid \\
\hline Y1.2 & 0,901 & 0,05 & 0,002 & Valid \\
\hline Y1.3 & 0,917 & 0,05 & 0,001 & Valid \\
\hline
\end{tabular}

Berdasarkan tabel di atas didapatkan bahwa untuk setiap indikator nilai $r_{\text {hitung }}>r_{\text {tabel }}$ dan nilai Sig $<0,05$, sehingga dapat diketahui bahwa setiap indikator digunakan valid sehingga mampu mengukur dengan baik apa yang diteliti.

Tabel 6. Hasil Uji Reliabilitas

\begin{tabular}{|c|c|c|c|}
\hline Variabel & $\begin{array}{c}\text { Cronbach's } \\
\text { Alpha }\end{array}$ & $\begin{array}{c}\text { Nilai } \\
\text { minimal }\end{array}$ & Ket \\
\hline Harga & 0,809 & 0,600 & Reliabel \\
\hline & 0,769 & 0,600 & Reliabel \\
\hline $\mathrm{N}$ & 0,775 & 0,600 & Reliabel \\
\hline $\begin{array}{c}\text { Loyalitas } \\
\text { pelanggan }\end{array}$ & 0,832 & 0,600 & Reliabel \\
\hline
\end{tabular}

Berdasarkan tabel di atas didapatkan bahwa untuk setiap variabel nilai Cronbach's Alpha $>0,600$, sehingga dapat diketahui bahwa jika semua variabel yang digunakan dapat dipercaya dan diandalkan sebagai alat pengumpul data (reliabel). 


\section{Uji Asumsi Klasik}

Pada penelitian ini digunakan uji asumsi klasik yaitu uji normalitas, uji multikolinieritas, dan uji heteroskedastisitas

\section{Gambar 2. Hasil Uji Normalitas}

One-Sample Kolmogorov-Smirnov Test

\begin{tabular}{|ll|r|}
\hline & & $\begin{array}{c}\text { Unstandardi } \\
\text { zed } \\
\text { Residual }\end{array}$ \\
\hline & Mean & 100 \\
Normal Parameters & Stb. & $0 \mathrm{E}-7$ \\
& Deviation & .44467907 \\
Most Extreme & Absolute & .048 \\
Differences & Positive & .048 \\
Kolmogorov-Smirnov Z & Negative & -.048 \\
Asymp. Sig. (2-tailed) & .484 \\
\hline
\end{tabular}

a. Test distribution is Normal.

b. Calculated from data.

Berdasarkan hasil di atas, didapatkan bahwa nilai signifikansi sebesar 0,973 lebih besar dari pada 0,05 sehingga dapat disimpulkan jika data regresi terdistribusi normal.

Tabel 7. Hasil Uji Multikolinearitas

\begin{tabular}{|c|c|c|c|c|}
\hline Variabel & Toleransi & $\begin{array}{c}\text { Batas } \\
\text { minimum } \\
\text { toleransi }\end{array}$ & VIF & $\begin{array}{c}\text { Batas } \\
\text { maksimum } \\
\text { VIF }\end{array}$ \\
\hline Harga & 0,552 & 0,100 & 1,811 & 10,000 \\
\hline $\begin{array}{c}\text { Kualitas } \\
\text { Produk }\end{array}$ & 0,613 & 0,100 & 1,631 & 10,000 \\
\hline Brand Love & 0,384 & 0,100 & 2,601 & 10,000 \\
\hline
\end{tabular}

Berdasarkan hasil di atas, didapatkan nilai toleransi semua variabel lebih dari 0,100 dan nilai VIF kurang dari 10,000 maka dapat disimpulkan bahwa regresi bebas dari gejala multikolinieritas. 


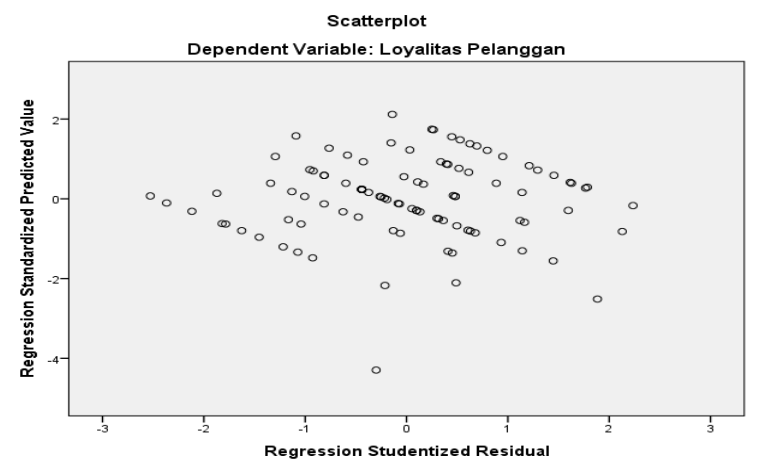

Gambar 3. Hasil Uji Heteroskedastisitas

Berdasarkan hasil di atas, didapatkan bahwa gambar tidak membentuk pola yang jelas dan titik-titik menyebar di atas dan di bawah angka nol pada sumbu Y, maka dapat disimpulkan bebas heteroskedastisitas

\section{Pengujian Hipotesis}

Berikut hasil uji t (uji parsial) untuk setiap variabel.

Tabel 8. Hasil uji t (uji parsial)

\begin{tabular}{|l|c|c|c|}
\hline \multicolumn{1}{|c|}{ Variabel } & $\mathbf{t}_{\text {hitung }}$ & $\mathbf{t}_{\text {tabel }}$ & Sig \\
\hline Harga & 0,283 & 2,859 & 0,005 \\
\hline Kualitas Produk & 0,257 & 2,568 & 0,012 \\
\hline Brand Love & 0,404 & 3,042 & 0,003 \\
\hline
\end{tabular}

Pada tabel tersebut diatas menujukkan bahwa pada uji parsial (uji t), variabel harga memiliki nilai t hitung sebesar 2,859 dengan nilai sig sebesar 0,005 $<0,05$ maka variabel harga tidak memberikan pengaruh tetapi signifikan terhadap variabel loyalitas pelanggan. Oleh karena itu, dapat dinyatakan bahwa hipotesis H1 yaitu diduga harga berpengaruh signifikan terhadap loyalitas pelanggan di Indomaret GKB - Gresik dapat diterima.

Kemudian untuk variabel kualitas produk memiliki nilai t hitung sebesar 2,568 dengan nilai sig sebesar 0,012 < 0,05 maka variabel kualitas produk tidak memberikan pengaruh tetapi signifikan terhadap variabel loyalitas pelanggan. Oleh karena itu, dapat dinyatakan bahwa hipotesa $\mathrm{H} 2$ yaitu, diduga kualitas produk berpengaruh signifikan terhadap loyalitas pelanggan di Indomaret GKB - Gresik dapat diterima.

Selanjutnya untuk variabel brand love memiliki nilai t hitung sebesar 3,042 dengan nilai sig sebesar $0,003<0,05$ maka variabel brand love tidak memberikan 
pengaruh tetapi signifikan terhadap variabel loyalitas pelanggan. Oleh karena itu, dapat dinyatakan bahwa hipotesa $\mathrm{H} 3$ yaitu diduga brand love berpengaruh signifikan terhadap loyalitas pelanggan di Indomaret GKB - Gresik dapat diterima.

Berdasarkan hasil regresi yang dilakukan, dibuat sebuah persamaan regresi antara variabel harga, kualitas produk dan brand love terhadap loyalitas pelanggan. Berikut data yang dibutuhkan untuk persamaan regresi dimuat dalam tabel.

Tabel 9. Data Regresi

\begin{tabular}{|l|l|l|}
\hline Variabel & Simbol & Koefisien \\
\hline Loyalitas Pelanggan & $\mathrm{Y}$ & - \\
\hline Konstanta & - & 0,423 \\
\hline Harga & $\mathrm{X} 1$ & 0,283 \\
\hline Kualitas Produk & $\mathrm{X} 2$ & 0,257 \\
\hline Brand Love & $\mathrm{X} 3$ & 0,404 \\
\hline
\end{tabular}

Berdasarkan tabel di atas dibuat persamaan struktural sebagai berikut:

$$
Y=0,423+0,283 X_{1}+0,257 X_{2}+0,404 X_{3}+\varepsilon,
$$

Berdasarkan persamaan tersebut didapatkan bahwa nilai koefisien untuk X3 (Brand Love) lebih besar dari pada nilai koefisien X1 (Harga) dan X2 (Kualitas Produk). Hal ini menandakan bahwa brand love lebih berpengaruh daripada harga dan kualitas produk.

Tabel 10. Hasil uji koefisien determinasi $\left(\mathbf{R}^{2}\right)$

\begin{tabular}{|c|c|}
\hline Model & Adjusted $\mathbf{R}^{\mathbf{2}}$ \\
\hline 1 & 0,500 \\
\hline
\end{tabular}

Dari tabel di atas, didapatkan nilai Adjusted $\mathrm{R}^{2}$ sebesar 0,500 atau setara dengan 50\%. Dapat disimpulkan bahwa variabel independen (harga, kualitas produk, dan brand love) dapat menjelaskan dan mempengaruhi variabel dependen (loyalitas pelanggan) sebesar 50\%. Sisanya sebesar 50\% dapat dijelaskan oleh variabel lain yang tidak digunakan dalam penelitian ini.

\section{Pembahasan}

Berdasarkan hasil uji yang dilakukan, dapat diketahui bahwa harga, kualitas 
produk, dan brand love berpengaruh signifikan terhadap loyalitas pelanggan di Indomaret GKB - Gresik. Hasil yang didapatkan sesuai dengan beberapa penelitian terdahulu yang sudah dilakukan. Penelitian yang dilakukan oleh Untung Widodo (2015) dengan judul Pengaruh Harga dan Produk terhadap Loyalitas Konsumen dengan Kepuasan Konsumen sebagai Variabel Intervening. Hasil penelitian menunjukkan bahwa terdapat pengaruh yang signifikan antara harga dan produk terhadap loyalitas konsumen dan kepuasan konsumen. Kemudian penelitian oleh Ezra Hendri Noto dan lukmanul Hakim (2016) dengan judul Analisa Pengaruh Harga dan Kualitas Produk terhadap Kepuasan Pelanggan (Studi kasus Jasa Bengkel Alin Motor Semarang). Hasil dari penelitian antara lain semakin harga murah dan terjangkau maka kepuasaan pelanggan bengkel Alin motor Semarang akan meningkat.

Kemudian penelitian oleh Cindy Phasalita Widayatma \& Sri Puji Lestari (2018) dengan judul Pengaruh Kualitas Produk terhadap Loyalitas Konsumen dengan Kepuasan Konsumen sebagai Variabel Intervening. Hasil dari penelitian antara lain kualitas produk terbukti berpengaruh terhadap kepuasan konsumen, dimana kepuasan konsumen terbukti berpengaruh terhadap loyalitas konsumen Rifa Kuliner, dan kualitas produk terbukti berpenhgaruh terhadap loyalitas konsumen.

Berdasarkan pembahasan yang dilakukan, didapatkan bahwa hasil penelitian yang telah dilakukan yaitu harga, kualitas produk, dan brand love berpengaruh signifikan terhadap loyalitas pelanggan di Indomaret GKB - Gresik sesuai dengan kajian empiris yang telah dilakukan dan konsep dari para ahli. Karena itu, dapat ditarik kesimpulan yang valid berdasarkan penelitian.

\section{Kesimpulan}

Berdasarkan hasil analisis dan pembahasan, maka dapat ditarik kesimpulan sebagai berikut:

1. Harga memberikan pengaruh yang sangat baik terhadap peningkatan loyalitas pelanggan di Indomaret GKB - Gresik.

2. Kualitas produk memberikan pengaruh yang sangat baik terhadap peningkatan loyalitas pelanggan di Indomaret GKB - Gresik. 
3. Brand love memberikan pengaruh yang sangat baik terhadap peningkatan loyalitas pelanggan di Indomaret GKB - Gresik.

Implikasi dari hasil penelitian adalah :

1. Harga produk di Indomaret GKB - Gresik sudah sangat baik. Hasil yang sangat baik tersebut harus bisa dijaga dan ditingkatkan. Beberapa temuan indikator harga yang harus diperhatikan adalah :

a. Indikator daya saing harga dengan produk sejenis, bisa dilakukan evaluasi untuk memberikan penawaran yang lebih baik daripada minimarket sejenis melalui memperpanjang jangka promosi produk bahkan juga bisa memberikan potongan harga / discount atau juga bisa buy one get one dengan harapan dapat meningkatkan daya saing dan loyalitas pelanggan.

b. Indikator kesesuaian harga dengan kualitas, dapat dilakukan evaluasi untuk memberikan promosi berupa potongan harga karena tidak dipungkiri bahwa pelanggan juga menginginkan produk berkualitas, apalagi kualitas premium dengan harga yang terjangkau dengan harapan dapat semakin meningkatkan loyalitas pelanggan.

2. Kualitas produk di Indomaret GKB - Gresik sudah baik. Hasil yang baik tersebut harus lebih ditingkatkan lagi. Beberapa temuan terkait indikator kualitas produk yang harus diperhatikan adalah :

a. Indikator kualitas produk yang dijual lebih baik dari perusahaan lain, bisa di evaluasi dengan melakukan sortir produk yang diberikan oleh vendor lebih teliti agar tidak ada produk dengan kemasan rusak yang dijual.

b. Indikator kualitas barang sesuai dengan apa yang diharapkan konsumen, bisa ditingkatkan dengan cara menjual barang yang sedang tren di masyarakat dan dengan upaya ini diharapkan dapat meningkatkan daya tarik pelanggan untuk melakukan pembelian di Indomaret.

3. Brand love Indomaret GKB - Gresik sudah baik, hasil yang baik tersebut harus lebih ditingkatkan lagi. Beberapa temuan terkait indikator kualitas produk yang harus diperhatikan adalah : 
a. Indikator mengenal merek sebagai merek yang sangat bagus, bisa ditingkatkan dengan promosi dan penyebaran pamflet agar pelanggan semakin kenal dengan Indomaret.

b. Indikator memiliki keterikatakan terhadap merek, bisa dilakukan dengan memberikan reward kepada pelanggan paling setia di Indomaret untuk mendorong pelanggan lainnya meningkatkan pembelanjaan di Indomaret.

4. Loyalitas pelanggan Indomaret GKB - Gresik sudah sangat baik. Hasil yang sangat baik tersebut harus lebih ditingkatkan lagi. Beberapa temuan terkait indikator kualitas produk yang harus diperhatikan adalah :

a. Say positive things dapat ditingkatkan dengan meningkatkan kualitas pelayanan agar pelanggan bisa menceritakan pengalaman berbelanja yang berbeda dengan minimarket lainnya.

Berdasarkan penelitian yang telah dilakukan, maka beberapa saran yang dapat diberikan antara lain:

1. Saran untuk manajemen Indomaret GKB - Gresik yaitu perlu dilakukan evaluasi terhadap produk yang dikirimkan oleh supplier, pelatihan untuk meningkatkan kualitas pelayanan, melakukan observasi promosi pada minimarket lain agar bisa bersaing harga produk, memperpanjang masa promosi produk, memberikan discount produk, dan menjual produk yang sedang tren. Dengan begitu diharapkan dapat meningkatkan aktivitas penjualan dan membuat pelanggan semakin mencintai minimarket Indomaret.

2. Saran untuk peneliti selanjutnya adalah perlu dilakukan penelitian lebih lanjut mengenai harga, kualitas produk, dan brand love terhadap loyalitas pelanggan Indomaret kedepannya agar mendapatkan hasil penelitian yang khusus dan mendetail pada Indomaret GKB - Gresik. Dengan begitu dapat ditempuh langkah yang lebih baik lagi untuk meningkatkan harga, kualitas produk dan brand love agar pelanggan Indomaret GKB - gresik lebih loyal lagi untuk melakukan aktivitas pembelanjaan di Indomaret GKB - Gresik. 


\section{DAFTAR PUSTAKA}

\section{Literatur Buku}

Abdullah, Thamrin \& Francis Tantri. 2012. Manajemen Pemasaran. Jakarta: Rajawali Pers

Agus Hermawan, 2012. Komunikasi Pemasaran. Jakarta:Erlangga.

A.S Munandar, 2001. Psikologi Industri danOrganisasi. Depok:Penerbit Universitas Indonesia (UI Press).

Buchari Alma. 2001. Pengantar Bisnis, Bandung : Alfabeta.

Buchari Alma, (2011), Manajemen Pemasaran dan Pemasaran Jasa, Cetakan Kesembelian, Alfabeth, Bandung.

Buchari Alma, 2013. Manajemen Pemasaran dan Pemasaran Jasa. Bandung: Alfabeta.

Danang, Sunyoto. 2012. Manajemen Sumber Daya Manusia. Jakarta: PT Buku Seru

Darmawi, Herman. (2006). Manajemen Asuransi. Jakarta: Bumi Aksara.

Djaslim Saladin, Yevis Oesman, 2002, "Intisari Pemasaran dan Unsur Pemasaran",

Penerbit : Lindakarya, Bandung.

Durianto,Sugiarto dan Tony Sitinjak, 2001. Strategi Menaklukkan Pasar Melalui. Riset Ekuitas dan Perilaku Merek, PT. Gramedia Pustaka.

Fajar, Laksana, 2008. Manajemen Pemasaran. Yogyakarta: Penerbit Graha Ilmu.

Fuad, Anis dan Kandung Sapto Nugroho. 2014. Panduan Praktis Penelitian

Kualitatif. Yogyakarta: Graha Ilmu. Gitosudarmo, Indriyo. 2001. Manajemen strategi. Yogyakarta: BPFE Yogyakarta.

Griffin, W, Ricky dan Ronald J Ebert. 2002. Management, Erlangga, Jakarta.

Griffin, Jill. 2005. Customer Loyalty: Menumbuhkan \& Mempertahankan Kesetiaan Pelanggan. Jakarta : Erlangga

Harini. 2008. Penetapan Harga ,Makro Ekonomi Pengantar, Pt Gramedia

Hasibuan, Malayu S.P, 2003, Manajemen Sumber Daya Manusia, Edisi Revisi, Bumi Aksara, Jakarta.

Kotler, Philip, 2006. Manajemen Pemasaran, Edisi Pertama. Indonesia: PT. Indeks Kelompok Gramedia.

Kotler, Philip and Gary Armstrong, 2008. Prinsip - Prinsip Pemasaran, Edisi 12 
Jilid 1, Jakarta:Erlangga.

Kotler, Philip dan Gary Armstrong, 2009. Prinsip - Prinsip Pemasaran, Edisi 12, Jilid 2. Jakarta:Erlangga.

Kotler, Philip and Kevin Lane Keller, 2016. Marketing Managemen, 15th Edition, Pearson Education,Inc.

Manullang, M dan Marihot A.M.H Manullang, 2004. Manajemen Personalia. Yogyakarta: Gajah Mada university Press.

Messier, William F., Glover Steven M. Jr, Prawitt Douglas F Jr. (2000). Auditing and Assurance Serviced Systematic Approach, Second Edition International Edition, Irwin McGraw-Hill Co., New York.

Rangkuti, Freddy (2002), Measuring Customer Satisfaction, Penerbit PT Gramedia Pustaka Utama, Jakarta

Robbins, P. Stephen dan Mary Coulter, 2010. Manajemen, diterjemahkan oleh Bob Sabran, Wibi Hardani. Erlangga:Jakarta.

Siregar, Syofian. 2013. Metode Penelitian Kuantitatif. Jakarta: PT Fajar Interpratama Mandiri.

Setiadi, Nugroho J. 2010. Perilaku Konsumen. Jakarta: Kencana.

Stanton, William, J., (2001), Prinsip-prinsip Pemasaran, Jilid Ketujuh, Penerbit Erlangga, Jakarta.

Stone, Raymond J. (2005). Human Resources Management; . Fifth Edition. Australia, Willey.

Sumarni, Murti dan John Soeprihanto. (2010). Pengantar Bisnis (Dasar-dasar Ekonomi Perusahaan). Edisi ke 5. Yogyakarta: Liberty Yogyakarta. Terry, George R., 1993, Prinsip-prinsip Manajemen, Bumi Aksara, Jakarta.

Sutisna., 2003, Perilaku Konsumen \& Komunikasi Pemasaran, Cetakan Ketiga, Bandung: PT Remaja Posdakarya.

Terry, George dan Leslie W. Rue. 2010. Dasar - dasar Manajemen. Cetakan kesebela. Jakarta: PT Bumi Aksara.

Tjiptono, Fandy. 2002. Strategi Pemasaran. Edisi Kedua. Yogyakarta:Andi.

Tjiptono, Fandy. 2008. Strategi Pemasaran. Edisi Ketiga. Yogyakarta:Andi.

Tjiptono, Fandi. 2015. Strategi Pemasaran. Edisi 4: Andi 
Utami Christina Widya. 2008. Manajemen barang dagang dalam bisnis ritel. Malang : Penerbit Bayumedia Publishing.

\section{Jurnal}

Albert, N., \& Merunka, D. 2013. The role of brand love in consumer-brand relationships. Journal of Consumer Marketing, 30(3), 258-266

Bursan, Rinaldi.2009. Tanggapan Konsumen Atas Bauran Pemasaran Rokok Sampoerna A Mild (Stufi Kasus pada Mahasiswa S1 Fakultas Ekonomi UNILA). JBM N0. 6 Vol.1.

Cindy Phasalita Widyatma. 2018. Pengaruh Kualitas Produk Terhadap Loyalitas Konsumen dengan Kepuasan Konsumen sebagai Variabel Inetervening (Studi Kasus Pada Rifa Kuliner Kendal). Serat Acitya Jurnal Ilmiah UNTAG Semarang Vol 7.

Dua Lembang, Rosvita. 2010. Analisis Pengaruh Kualitas Produk, Harga, Promosi, dan Cuaca terhadap Keputusan Pembelian Teh siap Minum dalam Kemasan Merek Teh Botol Sosro. Fakultas Ekonomi Universitas Diponegoro Semarang.

Ezra Hendri Noto \& Lukmanul Hakim. 2016. Analisis Pengaruh harga Produk dan Kualitas Produk terhadap Kepuasan Pelanggan (Studi Kasus Jasa Bengkel Alin Motor Semarang). Among Makarti Vol 9 No 17.

Hidayat, R. 2009. Pengaruh Kualitas Layanan, Kualitas Produk dan Nilai Nasabah terhadap Kepuasan dan Loyalitas Nasabah Bank Mandiri. Jurnal Manajemen dan Kewirausahaan. Vol. 11. No. 1. Teknik Industri. Madura: Universitas Trunojoyo.

Hwang, J., \& Kandampully, J. (2012). The role of emotional aspects in younger consumerbrand relationships. Journal of Product \& Brand Management, $21,98-108$.

Najmi Syarief, Salma, \& Rewindinar. 2015. Pengaruh Brand Activation Alfamart dan Indomart dalam Membangun Loyalitas Konsumen. Kalbisocio Vol 2. Sahnaz Ubud \& Susan Ubud. 2016. Strategi Kualitas Hubungan Merek, Komitmen, Kecintaan Terhadap Loyalitas Merek pada Restoran Waralaba. MIX 
Jurnal Ilmiah Manajemen Vol 3.

Septina Dwi Mayasari. 2011. Pengaruh Kualitas Produk dan Harga terhadap Loyalitas melalui Kepuasan Konsumen. Jurnal Ekonomi Bisnis.

Untung Widodo. 2015. Pengaruh Harga dan Produk Terhadap Loyalitas Konsumen dengan Kepuasan Konsumen sebagai Variabel Intervening. Buletin Bisnis dan Manajemen Vol 1.

Zeithaml. VA. Bitner MJ. 2003. Service Marketing: Integrating Customer Foucs Across The Firm. \#rd Edition. Boston: McGraw Hill/Irwin. 